\title{
The Addition of Red Betel Leaf Extract (Piper crocatum) in the Feed of Vannamei Shrimps (Litopenaeus vannamei) for Vibriosis Prevention
}

\author{
Fariq Azhar ${ }^{1^{*}}$, Muhammad Junaidi ${ }^{1}$, Bagus Dwi Hari Setyono ${ }^{1}$ and Andre Rachmat ${ }^{1}$ \\ ${ }^{1}$ Study Program of Aquaculture, Faculty of Agriculture, Universitas Mataram, Jl. Pendidikan 37, \\ Mataram 83125, West Nusa Tenggara, Indonesia
}

*Correspondence :

fariqazhar@unram.ac.id

Received : 2020-03-17

Accepted : 2021-07-30

Keywords :

Red betel leaf, Vibriosis, Vannamei shrimp, Feed

\begin{abstract}
Vibriosis is a type of shrimp disease caused by Vibrio sp. In the disease control of consumption biota, it is highly recommended to use natural ingredients that are not carcinogenic, one of which is red betel leaves (Piper crocatum). This study aims to determine the best dose of red betel leaf extract ( $P$. crocatum) mixed in Vannamei shrimp feed to prevent vibriosis. In this study, shrimps were reared for 40 days at a density of $20 \mathrm{fish} /$ container. The treatments included positive control, P1 (without extract + bacterial infection), negative control P2 (without extract and without bacterial infection), P3 (0.5\% extract + bacterial infection), P4 (1\% extract + infection), and P5 (2\% extract + bacterial infection). The application of red betel leaf extract at a dose of $0.5 \%$ resulted in $75 \%$ survival after infection with $V$. parahaemolyticus, Vannamei shrimps of THC $7.70 \times 106$ cells/mL, and DHC (hyaline $82.94 \%$ granular $20.10 \%$ ). The number of bacteria and the number of vibrio in the intestine were $52 \times 10^{8} \mathrm{CFU} / \mathrm{mL}$ and $12 \times 10^{8} \mathrm{CFU} / \mathrm{mL}$ accordingly. The best dose was obtained at P3 (Feed $+0.5 \%$ red betel leaf extract), seen from the increase in survival rate, the number of hemocytes, differential haemocyte counts, and a decrease in total bacteria, so the application of red betel leaf extract can be used in the cultivation of Vannamei shrimps as an immunostimulant.
\end{abstract}

\section{INTRODUCTION}

Vannamei shrimp species are increasingly being cultivated because they have high economic value and high market demand. In addition, physiologically Vannamei shrimps are in great demand by cultivators because it has a relatively fast growth rate so that the production period is shorter (Purnamasari et al., 2017). However, disease attacks are a major threat in shrimp culture (Chang et al., 2012), one of which is vibriosis caused by Vibrio sp. bacteria (Chandrakala and
Menaka, 2017). The mortality rate of Vannamei shrimps that are attacked by vibriosis is recorded at $80-100 \%$ and is pathogenic (Annisa et al., 2015). Treatment of bacterial-infected Vannamei shrimps with synthetic antibiotics can increase bacterial resistance (Putri et al., 2015), so antibiotics from natural ingredients that are more environmentally friendly and not carcinogenic are highly needed. One of the natural ingredients 
that can be used is red betel leaves (Piper crocatum).

Red betel leaves ( $P$. crocatum) are plants that are widely used in bacterial control. Annisa et al. (2015) stated that red betel leaves can be utilized as a natural antibacterial and antifungal material so that it can inhibit the growth of Staphylococcus aureus, Escherichia coli, Salmonella sp., Klebsiella, and Pasteurella as well as kill Candida albicans. Vibriosis attacks can be prevented through the active ingredients contained in red betel leaf extracts such as flavonoids, alkaloids, tannins, polyphenolic compounds, and essential oils (Puspita et al., 2018). These flavonoid compounds play a role in preventing cell oxidation and increase the immune system for the body's defense of Vannamei shrimps, while alkaloids play a role in inhibiting the process of the formation of the peptidoglycan component of bacterial cells so that these cells are not formed (Syahida et al., 2013).

Through this research, red betel leaf extract was added to the Vannamei shrimp feed with different doses. Therefore, the quite virulent attack of $V$. parahaemolyticus bacteria can be prevented through the administration of betel leaf extract with the right dose because it will affect the health of Vannamei shrimps. This study aims to determine the effect of the dose of red betel leaves ( $P$. crocatum) on Vannamei shrimp feed for the prevention of vibriosis.

\section{METHODOLOGY}

\section{Place and Time}

This research was conducted for 60 days in January-April 2020 at the Aquaculture Laboratory, Department of Fisheries and Marine Sciences, Faculty of Agriculture, University of Mataram.

\section{Research Materials}

The tools used in this study were containers, blowers, Petri dishes, ose needles, autoclaves, Erlenmeyer, analytical balances, micropipettes, syringes, haemocytometers, microscopes, driglaski, glass slides, hot plates, test tubes, and serological pipettes. The materials used in this study were PL-20 shrimp, commercial feed, seawater, red betel leaf extract, TCBS media, liquid SWC media, TSA media, 75\% alcohol, pure isolate of Vibrio parahaemolyticus bacteria, Giemsa dye, 10\% EDTA, $0.9 \% \mathrm{NaCl}$ solution, trisodium citrate, and methanol.

\section{Research Design}

The treatment consisted of positive control (P1) in which the feed was not given extract and infected with bacteria, and negative control (P2) in which the feed was not given extract and infected with $\mathrm{NaCl} 0.9 \%$, (P3) in which the feed was given $0.5 \%$ red betel extract and infected with bacteria, (P4) in which the feed was given $1 \%$ red betel extract and infected with bacteria, and (P5) in which the feed was given $2 \%$ red betel extract and infected with bacteria at doses of $0.5 \%, 1 \%$, and $2 \%$. Bacterial isolates obtained from BKIPM Mataram City were re-cultured and purified, and then recharacterization and total plate count (TPC) were performed. The isolates of $V$. parahaemolyticus used were cultured in 25 $\mathrm{ml}$ of liquid SWC medium for 18 hours in a water shaker at $29^{\circ} \mathrm{C}$.

\section{Work Procedure}

The initial stage of this study was to make extracts using the maceration method of powdered red betel with $96 \%$ ethanol, which was then filtered and evaporated with a Rotary Vacuum Evaporator at a temperature of $50{ }^{\circ} \mathrm{C}$ until a concentrated extract with a concentration of $100 \%$ was obtained (Putri et al., 2015). In the next stage, the maintenance of PL 20 seeds was conducted for 40 days to be later injected with a pure isolate of $V$. parahaemolyticus bacteria obtained from semisolid media with a density of $10^{6} \mathrm{CFU} / \mathrm{mL}$ as much as $1 \mathrm{~mL} /$ head on day 45 (Sarjito et al., 2015). Furthermore, observations were made after 7 days post-infection. 


\section{Container and Fish Testing}

The seeds used were 20 days old or PL-20 and weighed $0.02 \mathrm{~g}$ /individual with a stocking density of $20 \mathrm{fish} /$ container. The seeds came from the Center of Superior Shrimp and Oyster Production (BPIUUK) Karangasem Bali which was selected based on the weight of the seeds. Before being put into the research container, the seeds were adapted for 1 week in a reservoir. The container used in this study was a plastic container with a size of $40 \times 30 \times 28 \mathrm{~cm}$, with a volume of seawater of $20 \mathrm{~L}$ and a salinity of $30 \mathrm{ppt}$ per container, equipped with aeration devices, Pvc shelters, and water changes with siphoning done every day in the morning.

\section{Test Feed}

During the study, the shrimps were fed with crumble 681 feed which had a protein content of $30 \%$ mixed with red betel leaf extract. The making of red betel leaf extract included the process of the washing process, drying, and pollinating the red betel leaves. Afterward, the maceration process was carried out using 96\% methanol. Then, the material was filtered 3 times to obtain a thick extract which was concentrated using a Rotary Vacuum Evaporator at a temperature of $50^{\circ} \mathrm{C}$ (Setiawan et al., 2016). Following this, the extract was mixed with the feed until evenly distributed. Shrimps were fed as much as $5 \%$ of the weight of the biomass per aquarium. Feeding was done 3 times a day, specifically at $09.00 ; 15.00$, and 21.00 WITA with doses of $0.5 \%, 1 \%$, and $2 \%$ accordingly.

\section{Data Analysis}

Several parameters which were tested in this study were survival rate (SR) by taking into account the number of live shrimps at the beginning and end of the study, total hemocyte count (THC) which was carried out by taking $0.1 \mathrm{ml}$ of shrimp hemolymph from the base of the first swimming leg using a syringe which had already contained $0.3 \mathrm{ml}$ of $3.8 \%$ Sodium citrate anticoagulant. Afterward, the obtained mixture was homogenized, and the mixture was dripped into the hemocytometer after the first drop had been removed. Then, the number of cells per $\mathrm{ml}$ was observed and counted under a microscope with 400 times magnification.

Differential hemocyte count (DHC) was determined by some processes in which the hemolymph of shrimps was taken, and then it was dripped on an object glass and made into smear preparation before air-dried and then given fixation with $100 \%$ methanol for 5 minutes. After that, it was air-dried again and then stained with $10 \%$ Giemsa solution for 10 minutes. The preparations were observed using a microscope and distinguished by the number of hyaline and granular cells. Calculation of total bacteria and total vibrio were carried out at the end of the study, in which intestines were taken and homogenized in phosphate-buffered saline (PBS) solution.

Bacterial counts used the cup count method, using SWC (Sea Water Complete) media for the calculation of TBC (Total Bacterial Count), and TCBS (Thiosulfate Citrate Bile Salts Sucrose) specific media for VBC (Vibrio Bacterial Count) calculations. The data were later processed statistically in one way - ANOVA using the SPSS application (Version 16.0) at a 95\% confidence level $(\mathrm{P}<0.05)$. Significantly different results were further tested using Tukey HSD.

\section{RESULTS AND DISCUSSION}

The survival of Vannamei shrimps after infection can be seen in P2 or negative control, which showed a figure of $76.67 \%$, P3 of $75.00 \%$, P4 of $61.67 \%$, and P5 of $60.00 \%$, while the smallest figure was in P1 of $26.67 \%$ (Figure 1). However, after the One-Way Annova test and Tukey's follow-up test, the administration of red betel leaf extract had a significant effect $(\mathrm{P}>0.05)$ on $\mathrm{P} 1$ or positive control compared to other treatments. This means that the positive control (feed not given extract and infected with bacteria) was significantly different from all treatments. 
The total hemocyte count of Vannamei shrimps after infection was noted in $\mathrm{P} 3$ of $7.70 \times 10^{6}$ cells $/ \mathrm{ml}, \mathrm{P} 4$ of $6.25 \times 10^{6}$ cells $/ \mathrm{ml}$, P5 of $5.55 \times 10^{6}$ cells/ml, negative control (P2) of $3.89 \times$ 106 cells/ml, and positive control (P1) as the smallest figure of $3.15 \times 10^{6}$ cells $/ \mathrm{ml}$ (Figure 2). However, after the One-Way Annova test and Tukey further, test, the administration of red betel leaf extract showed a significant effect $(\mathrm{P}>0.05)$ between the control and other treatments, where P3, P4, and P5 were not significantly different but significantly different from P1 and P2, meaning that the positive and negative controls were significantly different from the treatment given red betel leaf extract.

Based on the results of DHC observations based on the numbers in Figure 3, the largest amount of hyaline was obtained at $82.94 \%$ in P3 and the smallest was obtained at $35.75 \%$ in $\mathrm{P} 1$. Meanwhile, the highest number of granulocytes was in P1 of $64.25 \%$ and the lowest was found in P4 of $17.06 \%$ (Figure 3). However, based on the One-Way Annova test, significant results were obtained $(\mathrm{P}<0.05)$ between positive controls P1 and P3, P4 and P5 with the addition of red betel leaf extract.

Based on the results of the total count of bacteria obtained after bacterial infection, the highest number was mostly found in P1, accounting for $136 \times 10^{8}$ $\mathrm{CFU} / \mathrm{mL}$ and the lowest was found in $\mathrm{P} 2$, accounting for $116 \times 10^{6} \mathrm{CFU} / \mathrm{mL}$. The number of $V$. parahaemolyticus in P1 of 66 $\times 10^{8} \mathrm{CFU} / \mathrm{mL}$ was the highest total vibrio, while the lowest was $\mathrm{P} 2$ of $64 \times 10^{6}$ $\mathrm{CFU} / \mathrm{mL}$ (Table 1).

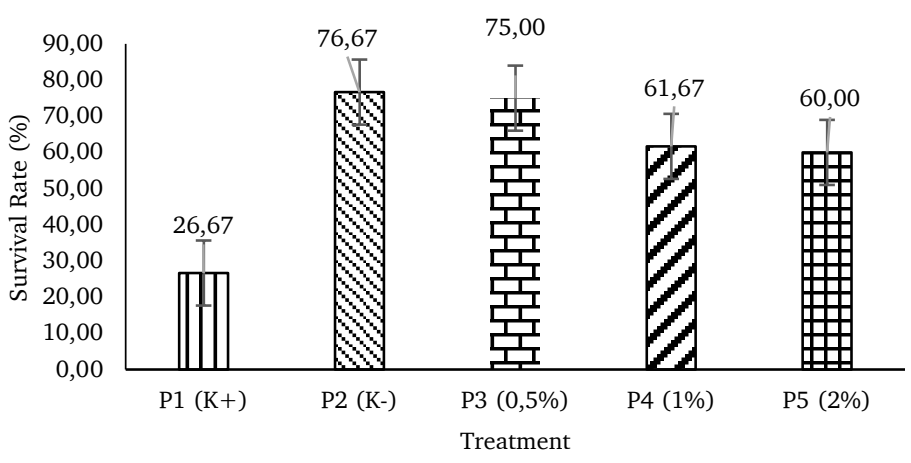

Figure 1. Vannamei shrimp survival after infection with V. parahaemolyticus.

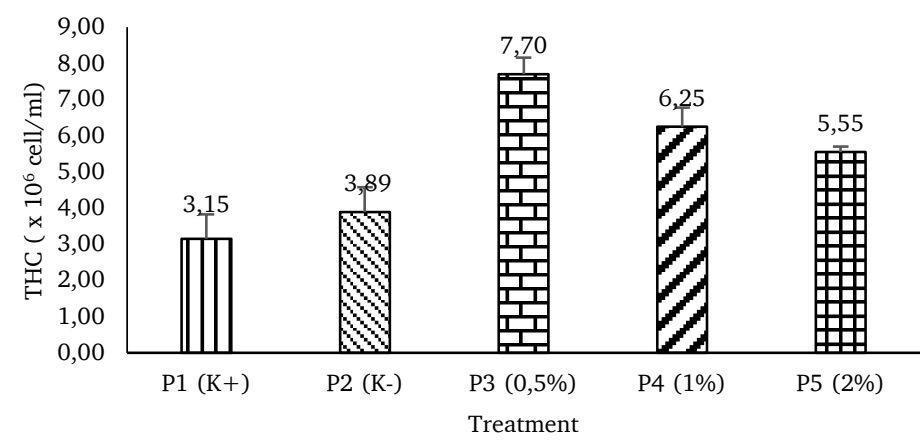

Figure 2. Total Haemocyte Count of Vannamei shrimps after $V$. parahaemolyticus infection. 


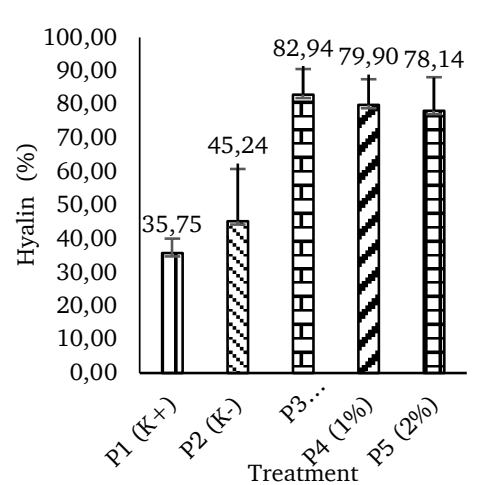

(A)

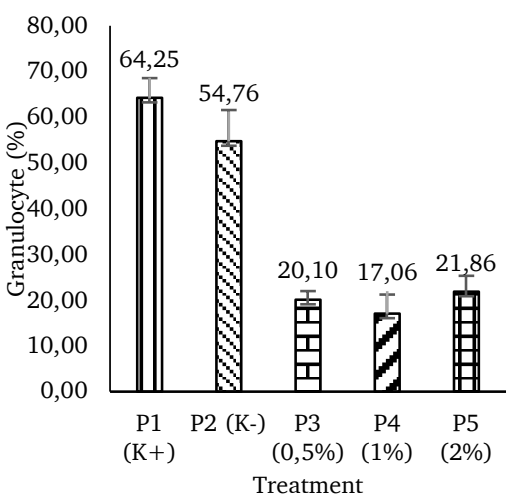

(B)

Figure 3. Vannamei shrimp survival after infection with $V$. parahaemolyticus; A (hyaline); B (granulocytes).

Table 1. Total bacteria and total Vibrio.

\begin{tabular}{ccc}
\hline Treatment & Total Bacteria $(\mathrm{cfu} / \mathrm{ml})$ & Total Vibrio $(\mathrm{cfu} / \mathrm{ml})$ \\
\hline P1 $(\mathrm{K}+)$ & $136 \times 10^{8}$ & $66 \times 10^{8}$ \\
P2 $(\mathrm{K}-)$ & $116 \times 10^{6}$ & $54 \times 10^{6}$ \\
P3 $(0,5 \%)$ & $52 \times 10^{8}$ & $12 \times 10^{8}$ \\
P4 (1\%) & $66 \times 10^{8}$ & $23 \times 10^{8}$ \\
P5 $(2 \%)$ & $75 \times 10^{8}$ & $34 \times 10^{8}$ \\
\hline
\end{tabular}

Based on the results of this study (Figure 1), there was a high survival rate in P2 (76.67\%), which acted as a negative control because the treatment was not infected with $V$. parahaemolyticus bacteria compared to other treatments that were infected with bacteria. However, P1 (26.67\%) which was a positive control without extract and infection with bacteria showed the lowest survival rate. In general, the survival of shrimp post-larvae was closely related to the quality of feed, which can optimize digestive function to provide good body resistance (Nimrat et al., 2011).

The concentration of $V$. parahaemolyticus bacteria as much as 104 $\mathrm{CFU} / \mathrm{mL}$ injected intramuscularly was able to cause $50 \%$ mortality in the test shrimp population within one week (Rahmanto et al., 2014). Vibrio sp. is the causative agent of vibriosis in shrimps, resulting in mortality reaching 80-100\% (Annisa et al., 2015). Vibrio sp. is a normal flora that can increase in conditions that are not favorable for shrimps (Chandrakala and Menaka, 2017). In Oktaviana's (2014) study, the highest survival rate was found in negative controls not being infected with $V$. harveyi. Based on Azhar's (2018) research, to increase the survival value, it is necessary to increase the immune response in shrimps as a preventive measure against pathogen attack and resistance.

The use of red betel leaf extract affected the number of hemocytes, thereby increasing the resistance of shrimps against $V$. parahemolyticus attack. Based on the results of this study, the highest number of hemocytes as described in Figure 2 was obtained in P3 which was treated with $V$. parahemolyticus infection and the addition of red betel leaf extract as much as $2 \%$, accounting for $7.70 \times 10^{6}$ cells/mL, while P1 (positive control) obtained the lowest number of hemocytes overall treatments, accounting for $3.15 \times$ $10^{6}$ cells $/ \mathrm{mL}$. Increased THC can increase shrimp immunity, which leads to disease resistance (Hsieh et al., 2008). Based on research by Rohmin et al. (2017), an increase in the number of hemocytes indicates an immune response of Vannamei shrimps as seen from the number of parasites and the decreased impact of infection. These hemocytes themselves play a role in the crustacean body's defense process by reducing foreign 
particles in the shrimp body (Hauton, 2012).

Based on the results of the study, the highest number of hyaline cells was noted in P3, accounting for $82.94 \%$ with the number of granulocytes of $20.10 \%$. The indicator of the occurrence of pathogenic infection, which can cause inflammation as a form of non-specific defense that can be influenced by bacteria, fungi, and viruses, can be seen from the number of shrimps hemocytes (Rohmin et al., 2017). The increase in hemocytes is related to the uptake of the extract as an immunostimulant in the Vannamei shrimp's body, thereby encouraging hemocyte activities to degranulate and phagocytose (Darwantin et al., 2016). The increased number of hyaline cells is also associated with phagocytic activities, while the granular cells themselves play a role in the production of melanin in the cytotoxic process (Hauton, 2012).

At the end of the study, the number of bacteria and the number of vibrios showed a significant increase between the control and the treatment groups were given red betel leaf extract, as shown in Table 1. In the treatment group given red betel leaf extract, after looking at the whole body of the infected shrimps, the number of bacteria and the number of vibrios were much lower than that in the treatment groups not given red betel leaf extract as an immunostimulant. This is thought to be due to the active ingredient as an antibacterial in red betel leaves.

In Kartika et al.'s research (2018), red betel leaves in the form of particles with a micrometer size are effective in inhibiting bacterial growth by penetrating bacterial cells. Prevention of vibriosis can be done through the provision of natural ingredients of red betel leaf extract which contains active ingredients such as flavonoids, alkaloids, tannins, polyphenolic compounds, and essential oils (Puspita et al., 2018). Flavonoid compounds play a role in preventing cell oxidation and in increasing the immune system for the body's defense of Vannamei shrimps, while alkaloids play a role in inhibiting the process of the formation of the peptidoglycan component of bacterial cells so that these cells are not formed (Syahida et al., 2013).

\section{CONCLUSION}

The best application of red betel leaf extract which was able to prevent the vibriosis attack was noted in P3 (Feed $+0.5 \%$ red betel leaf extract), which was seen from the increase in the survival rate, the number of hemocytes, differential hemocyte counts and a decrease in total bacteria.

\section{ACKNOWLEDGMENT}

The authors would like to thank the University of Mataram for facilitating and fully supporting the process of this research.

\section{REFERENCES}

Annisa, N., Sarjito and Prayitno, S.B., 2015. Pengaruh perendaman ekstrak daun sirih (Piper betle) dengan konsentrasi yang berbeda terhadap gejala klinis, kelulushidupan, histologi dan pertumbuhan udang vaname (Litopenaeus vannamei) yang diinfeksi Vibrio harveyi. Journal of Aquaculture Management and Technology, 4(3), pp.54-60. http://e journal-s1.undip.ac.id/index.php/ja $\mathrm{mt}$

Azhar, F., 2018. Aplikasi bioflok yang dikombinasikan dengan probiotik untuk pencegahan infeksi Vibrio parahaemolyticus pada pemeliharaan udang vaname (Litopenaeus vannamei). Journal of Aquaculture Science, 3(1), pp.128137. https://doi.org/10.31093/joas .v3i1.38

Chandrakala, N. and Menaka, R., 2017. Vibriosis detection and pathology. International Journal of Current Innovation Research, 3(3), pp.622626. https://www.journalijcir.com/ sites/default/files/issue-files/00427 -A-2017.pdf 
Chang, Y.P., Liu, C.H.,, Wu, C.C., Chiang, C.M., Lian, J.L. and Hsieh, S.L., 2012. Dietary administration of zingerone to enhance growth, nonspecific immune response, and resistance to Vibrio alginolyticus in Pacific white shrimp (Litopenaeus vannamei) juveniles. Fish \& Shellfish Immunology, 32(2), pp.284-290. https://doi.org/10.1016/j.fsi.2011. 11.017

Darwantin, K., Sidik, R. and Mahasari, G., 2016. Efisiensi penggunaan imunostimulan dalam pakan terhadap laju pertumbuhan, respon imun dan kelulushidupan udang vaname (Litopenaeus vannamei). Jurnal Biosains Pascasarjana, 18(2), pp.1-18. http://dx.doi.org/10.2047 3/jbp.v18i2.2016.123-139

Hauton, C., 2012. The scope of the crustacean immune system for disease control. Journal of Invertebrate Pathology, 110(2), pp.251-260. https://doi.org/10.101 6/j.jip.2012.03.005

Hsieh, S.L., Ruan, Y.H., Li, Y.C., Hsieh, P.S., Hu, C.H. and Kuo, C.M., 2008. Immune and physiological responses in Pacific white shrimp (Penaeus vannamei) to Vibrio alginolyticus. Aquaculture, 275(1-4), pp.335-441. http://dx.doi.org/10.1 016/j.aquaculture.2007.12.019

Kartika, E.P., Marchaban and Sudarsono, 2018. Aktivitas antibakteri minyak sirih merah (Piper crocatum Ruiz \& Pav.) dalam bentuk sediaan emulsi dan mikroemulsi. Majalah Farmaseutik, 14(2), pp.79-86. http:/ /dx.doi.org/10.22146/farmaseutik. v14i2.42597

Nimrat, S., Boonthai, T. and Vuthiphandchai, V., 2011. Effects of probiotic forms, compositions of and mode of probiotic administration on rearing of Pacific white shrimp (Litopenaeus vannamei) larvae and postlarvae. Animal Feed Science and Technology, 169(3-4), pp.244-258. https://doi.org/10.1016/j.anifeedsc i.2011.07.003
Oktaviana, A., 2014. Kajian pemberian sinbiotik dengan frekuensi berbeda untuk pencegahan ko-infeksi Infectious Myonecrosis Virus dan Vibrio harveyi pada udang vaname (Litopenaeus vannamei). Thesis. Institut Pertanian Bogor. Bogor.

Purnamasari, I., Purnama, D. and Utami, M.A.F., 2017. Pertumbuhan udang vaname (Litopenaeus vanamei) di tambak intensif. Jurnal Enggano, 2 (1), pp.58-67. https://doi.org/10.3 1186/jenggano.2.1.58-67

Puspita, P.J., Safithri, M. and Sugiharti, N.P., 2018. Antibacterial activities of sirih merah (Piper crocatum) leaf extracts. Current Biochemisrty, 5(3), pp.1-10. https://jurnal.ipb.ac.id/in dex.php/cbj/article/view/25403

Putri, A.M., Prayitno, S.B. and Sarjito, 2015. Perendaman berbagai dosis ekstrak daun bakau (Rhizophora apiculata) untuk pengobatan kepiting bakau (Scylla serrata) yang diinfeksi bakteri Vibrio harveyi. Journal of Aquaculture Management and Technology, 4(4), pp.141-149. http://ejournal-s1.undip.ac.id/inde x.php/jamt

Rahmanto, S.P., Sarjito and Chilmawati, D., 2014. Karakterisasi dan uji postulat koch bakteri genus Vibrio yang berasal dari media kultur massal mikroalga. Journal of Aquaculture Management and Technology, 3(4), pp.230-237. http:/ /ejournal-s1.undip.ac.id/index.php /jamt

Rohmin, M.F.T., Mahasari, G. and Rantam, F.A., 2017. Response analysis of urban vaname (Litopenaeus vannamei) which is exposed to crude protein Zoothamnium penaei oral and maintained in ponds. Jurnal Biosains Pascasarjana, 19(2), pp.143-157. http://dx.doi.org/10.20473/jbp.v1 9i2.2017.143-157

Sarjito, Apriliani, M., Afriani, D. and Haditomo, A.H.C., 2015. Agensia penyebab Vibriosis pada udang vaname (Litopenaus vannamei) yang 
dibudidayakan secara Intensif di Kendal. Jurnal Kelautan Tropis, 18(3), pp.189-196. https://doi.org/ 10.14710/jkt.v18i3.533

Setiawan, A.A., Megawati, S. and Nisa, D., 2016. Uji aktivitas ekstrak etanol daun sirih merah (Piper crocatum ruiz and pav) sebagai antiinflamasi pada tikus putih jantan galur Sprague-Dawley. Jurnal Farmagazine, 3(1), pp.1-6. https://d x.doi.org/10.47653/farm.v3i2.30

Syahida, I.E.A., Sarjito, Prayitno, S.B. and Lusiastuti, A.M., 2013. Pengaruh ekstrak daun sirih merah (Piper crocatum) terhadap profil darah dan kelulushidupan ikan mas (Cyprinus carpio) yang diinfeksi bakteri Aeromonas hydrophila. Journal of Aquaculture Management and Technology, 2(4), pp.94-110. http:// ejournal-s1.undip.ac.id/index.php/j fpk 